\title{
Penatalaksanaan emergensi pada trauma oromaksilofasial disertai fraktur basis kranii anterior
}

\author{
Agus Dwi Sastrawan*, Endang Sjamsudin**, Ahmad Faried*** \\ *Program Pendidikan Dokter Gigi Spesialis Bedah Mulut dan Maksilofasial, Fakultas Kedokteran Gigi, Universitas Padjadjaran, \\ Bandung, Jawa Barat, Indonesia \\ **Departemen Bedah Mulut dan Maksilofasial, Fakultas Kedokteran Gigi, Universitas Padjadjaran, Bandung, Jawa Barat, Indonesia \\ ***Departemen Bedah Saraf, Fakultas Kedokteran, Universitas Padjadjaran, Bandung, Jawa Barat, Indonesia \\ *JI Sekeloa Selatan No 1, Bandung, Jawa Barat, Indonesia; e-mail: sastrawandwi@ymail.com
}

Submisi: 12 Agustus 2016; Penerimaan: 21 Juni 2017; Publikasi online: 31 Agustus 2017

\begin{abstract}
ABSTRAK
Trauma oromaksilofasial disertai fraktur basis kranii merupakan kasus yang cukup banyak ditemukan di Instalasi Gawat Darurat Bedah Mulut dan Maksilofasial RSUP Dr. Hasan Sadikin Bandung. Penatalaksanaan emergensi bertujuan untuk melakukan tindakan yang tepat, mencegah komplikasi, serta konsultasi kepada bagian lain yang terkait. Seorang lakilaki usia 28 tahun datang dengan keluhan perdarahan dari mulut akibat kecelakaan motor kurang lebih 6 jam sebelum masuk rumah sakit. Pemeriksaan fisik ditemukan wajah asimetris, edema dan hematoma pada regio periorbita bilateral, terdapat rhinorrhea, serta bekas jahitan pada regio labiomental. Pemeriksaan intra oral tampak fraktur pada daerah maksila, palatum, parasimfisis, fraktur dentoalveolar, vulnus laserasi pada bibir atas, bibir bawah, palatum, gingiva, kesulitan membuka mulut, dan maloklusi gigi geligi. Tindakan emergensi bedah mulut dan maksilofasial dilakukan segera dan cepat dengan minimal intervensi pada rahang atas bertujuan untuk mencegah kebocoran cairan serebro spinal persisten, dan mencegah terjadinya infeksi. Manajemen luka jaringan lunak dan jaringan keras, melakukan reduksi, fiksasi dan imobilisasi fraktur, manajemen nyeri serta pemberian antibiotik. Penatalaksanaan emergensi pada trauma oromaksilofasial disertai fraktur basis kranii dilakukan segera dan cepat dengan minimal intervensi.
\end{abstract}

Kata kunci: basis kranii; fraktur; manajemen; oromaksilofasial

\begin{abstract}
Emergency management of oromaxillofacial trauma with anterior cranial base fracture. Oromaxillofacial trauma with cranial base fracture is a case that is quite commonly found in the ER of Oral and Maxillofacial Surgery Department at Dr. Hasan Sadikin General Hospital Bandung. Emergency management aims to take any appropriate action, prevent complications, and consult to other departments involved. A man aged 28 years came with bleeding from the mouth due to a motorcycle accident approximately 6 hours before admission to the hospital. Physical examination showed facial asymmetry, bilateral periorbital edema and hematoma, rhinorrhea, and stitches in labiomental area. Intraoral examination showed maxillary, palatal, parasymphisis, dentoalveolar fractures, lacerated wound on the upper lip, lower lip, palate, gingival, difficulty in opening the mouth, and malocclusion of the teeth. Immediate and rapid surgical and maxillofacial surgical emergency was performed with minimal maxillary intervention, aiming to prevent persistent spontaneous cerebrospinal fluid leak, and prevent infection. The management of soft tissue and hard tissue injury is by reduction, fixation and immobilization of fractures, management of pain and administration of antibiotics. In conclusion, the emergency management of oromaxillofacial trauma with cranial base fracture is promptly and rapidly carried out with minimal intervention.
\end{abstract}

Keywords: cranial base; fracture; management; oromaxillofacial

\section{PENDAHULUAN}

Trauma oromaksilofasial berhubungan dengan cedera pada wajah atau rahang yang disebabkan oleh kekuatan fisik, benda asing atau luka bakar, termasuk cedera pada salah satu struktur tulang, kulit dan jaringan lunak pada wajah. Setiap bagian dari wajah mungkin dapat terpengaruh, mata dengan otot-ototnya, saraf dan pembuluh darahnya mungkin mengalami cedera sehingga dapat menyebabkan gangguan penglihatan, diplopia, pergeseran posisi dari bola mata dan tulang rongga mata dapat retak akibat pukulan yang kuat. Sementara di rongga mulut dapat menyebabkan gigi geligi goyang atau terlepas, kerusakan jaringan lunak seperti edema, kontusio, abrasi, laserasi dan avulsi. ${ }^{1,2,3}$

Cedera kepala adalah cedera terbuka dan tertutup yang terjadi karena fraktur tengkorak, gegar serebri, memar serebri, leserasi dan 
perdarahan serebral subarakhnoid, subdural, epidural, intraserebral, batang otak. Klasifikasi cedera kepala berdasarkan Glasgow Coma Scale (GCS), adalah suatu skala dengan menilai respon pasien terhadap rangsangan yang diberikan dengan memperhatikan tiga reaksi yang terdiri dari reaksi membuka mata (Eye $(E))$, respon motorik (M), dan respon verbal (V). Hasil pemeriksaan kesadaran berdasarkan GCS disajikan dalam simbol (EMV), selanjutnya nilai-nilai tersebut dijumlahkan. GCS membagi tingkat keparahan cedera kepala menjadi cedera kepala ringan atau mild head injury (GCS 14-15), cedera kepala sedang atau moderate head injury (GCS 9-13) dan cedera kepala berat atau severe head injury (GCS 3-8).,5,5,67

Fraktur basis kranii adalah trauma pada dasar tengkorak atau basis kranii bisa terjadi secara langsung maupun tidak langsung, sehingga ada beberapa fraktur basis kranii yang terjadi sebagai akibat jejas lokal. Trauma langsung biasanya terjadi di daerah oksipital, mastoid, supraorbital, sedangkan yang tidak langsung biasanya terjadi pada wajah yang selanjutnya kekuataan tenaganya dihantarkan melalui tulang-tulang wajah atau rahang bawah. Kebocoran cairan serebro spinal menandakan adanya duramater yang robek, namun sebaliknya tidak semua fistula atau dura yang robek menimbulkan kebocoran cairan serebro spinal. ${ }^{7,8,9,10}$ Terdapat tiga jenis fraktur basis kranii antara lain: fraktur fossa anterior, fraktur fossa media dan fraktur fossa posterior. Pada fraktur fossa anterior rhinorrhea paling sering disebabkan oleh fraktur tulang frontal, ethmoid, dan sphenoid, duramater melekat pada tulang tipis di lantai fossa anterior. Daerah yang paling sering menyebabkan rhinorrhea adalah adanya fraktur di daerah cribiform/ ethmoid junction dan ethmoid. Fistula pada regio tersebut secara langsung akan berhubungan dengan kavitas nasal atau melalui ethmoid air cell. $7,8,9,10$

Fraktur fossa media adalah fraktur melalui os petrous yang memanjang ke telinga tengah dapat menyebabkan otorrhea jika membran timpani robek, atau ditemukannya otorhinorrhea jika kebocoran terjadi melalui tuba eustachius ke nasofaring. Antara 70-90 \% fraktur os temporal sejajar dengan sumbu panjang dari petrous ridge yang dapat merusak tulang pendengaran sehingga mengakibatkan gangguan pendengaran konduktif dan gangguan N.VII. Fraktur transversal $10-30 \%$ sering dihubungkan dengan defisit N.VIII, gangguan saraf sensorik pendengaran, dan parese wajah. Fraktur fossa posterior atau fraktur kranio-orbita, oculorhinorrhea dapat ditemukan apabila terjadi fraktur kranio-orbita dengan laserasi dari sakus konjungtiva yang memungkinkan kebocoran cairan serebro spinal dari mata. $7,8,9,10$

Salah satu komplikasi kebocoran cairan serebro spinal yang tidak diterapi adalah meningitis, dengan resiko terjadinya sekitar $25 \%$. Angka mortalitas terjadinya meningitis karena traumatik kebocoran cairan serebro spinal sekitar 10\%. Komplikasi terjadinya meningitis meningkat apabila pada keadaan kebocoran cairan serebro spinal persisten. Adanya fraktur tulang basal dapat menyebabkan terbukanya ruang subarakhnoid dengan dunia luar. Organisme yang sering ditemukan adalah Streptococcus pneumoniae dan Haemophilus influenza. Pemberian antibiotik profilaksis masih menjadi kontroversi. Antibiotik profilaksis pilihan yang dapat diberikan adalah kombinasi kotrimoxazol (trimethoprim-sulfamethoxazole) yang bekerja di cairan serebro spinal dan amoxicillin atau penicillin yang bekerja di mukosa hidung. ${ }^{7,10,11}$

Pencegahan komplikasi trauma oromaksilofasial dapat dilakukan dengan melakukan pemeriksaan yang lebih teliti dan lengkap serta konsultasi kepada bagian lain yang terkait. Trauma oromaksilofasial dapat menjadi kasus yang kompleks dan diperlukan keterlibatan multi spesialis dalam penatalaksanaannya. ${ }^{1,2,3}$ Tujuan dari penulisan studi kasus ini untuk memberikan informasi ilmiah penatalaksanaan emergensi trauma oromaksilofasial disertai fraktur basis kranii anterior.

\section{METODE}

Pasien laki-laki berusia 28 tahun datang ke Instalasi Gawat Darurat RSUP Dr. Hasan Sadikin Bandung dengan keluhan perdarahan dari mulut, dari anamnesis didapat bahwa kurang lebih 6 jam sebelum masuk rumah sakit, saat pasien sedang menumpang motor dengan menggunakan helm half face, dengan kecepatan sedang di daerah Dayeuh Kolot Bandung, tiba-tiba datang motor lain dari arah berlawanan dan menabrak motor pasien sehingga pasien terjatuh dengan mekanisme jatuh 
tidak diketahui. Kecelakaan disertai pingsan selama kurang lebih 30 menit, tidak terdapat mual dan muntah, dari anamnesis saksi mata didapat pula perdarahan hidung dan mulut. Pasien lalu dibawa ke Rumah Sakit Daerah setempat, dilakukan pemasangan infus, penjahitan luka di dagu serta foto rontgen kepala kemudian pasien di rujuk ke Instalasi Gawat Darurat RSUP Dr. Hasan Sadikin Bandung.

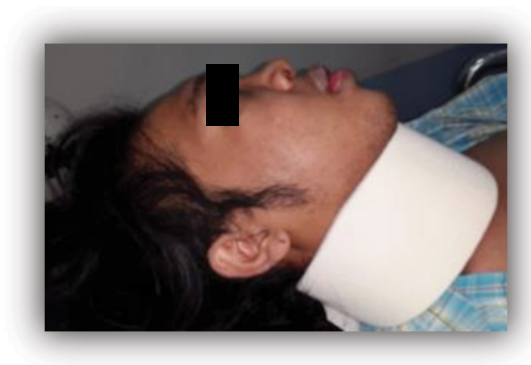

\section{Bandung.}

Penilain awal (primary survey) ditemukan A: Clear dengan C-spine control, B: Bentuk dan gerak dada simetris, Vesicular Breath Sound kanan sama dengan kiri, respirasi 23 kali per menit, C: Tekanan darah 120/90 mmHg, nadi 93 kali permenit, D: Penilaian klasifikasi cedera kepala dengan Glasgow Coma Scale GCS15 (E4M6V5) cedera kepala ringan. Pupil bulat isokhor diameter $3 \mathrm{~mm}$ kiri sama dengan kanan, tidak ada gangguan refleks cahaya, 
dan tidak ditemukan parese. Secondary survey ditemukan jejas luka abrasi pada regio leher dan dada. Pemeriksaan generalisata ditemukan kulit turgor positif, kepala wajah asimetris, terdapat edema dan hematoma pada regio periorbital bilateral, edema pada regio mandibula kanan, serta terdapat bekas jahitan pada regio labiomental dengan ukuran $2 \mathrm{~cm}$. Konjungtiva tidak anemis, sklera tidak ikterik. Jugular Vena Pressure tidak meningkat, kelenjar getah bening submandibular tidak teraba dan tidak sakit, bentuk dan gerak dada simetris, tidak ditemukan rongki dan whizing, bunyi jantung murni reguler, abdomen datar lembut, bising usus positif normal, ekstremitas akral hangat, dan capillary refill time kurang dari 2 detik.

Pemeriksaan intraoral terdapat laserasi pada bibir atas ukuran $3 \times 1 \times 0,5 \mathrm{~cm}$ dan pada mukosa bibir bawah ukuran $3 \times 1 \times 1 \mathrm{~cm}$ dasar otot, laserasi pada gingiva regio gigi $21-22$ ukuran $2 \times 0,5 \times 0,5 \mathrm{~cm}$ dan gingiva regio gigi $31-42$ ukuran $3 \times 1 \times 0,5 \mathrm{~cm}$ dasar tulang, laserasi pada regio palatum ukuran $3 \times 0,5 \times 0,5 \mathrm{~cm}$ dasar tulang. (lihat Gambar 1). Selanjutnya pasien dilakukan pemeriksaan darah lengkap dan faktor pembekuan darah dan didapat dengan hasil; PT: 9.8 detik; INR: 0.93 detik; APTT: 23.7 detik; $\mathrm{Hb}: 15 \mathrm{~g} / \mathrm{dL}$; Ht: 45\%; Leukosit : 16.300/ mm3; Eritrosit: 4.63 juta/uL; Trombosit: $277.000 /$ mm3; AST/ALT: 23/15 U/L; Ur/Kr: 28/0.73 mg/dL; GDS: $122 \mathrm{mg} / \mathrm{dL} ; \mathrm{Na} / \mathrm{K}:$ 133/3.6 mEq/L.Pasien juga dilakukan pemeriksaan penunjang berupa foto rontgen thoraks Antero Posterior (AP), foto servical, foto polos kepala AP dan lateral, foto water's serta foto panoramik.
Setelah dilakukan pemeriksaan fisik dan penunjang, pasien dikonsulkan ke bagian Bedah Saraf dengan temuan klinis saat kecelakaan pasien pingsan selama kurang lebih 30 menit, dan terdapat rhinorrhea. Diagnosis dari bagian Bedah Saraf Mild Head Injury dengan fraktur basis kranii anterior dan diagnosis dari bagian Bedah Mulut dan Maksilofasial fraktur Le fort II, fraktur palatum tipe II, fraktur parasimfisis mandibular dextra, fraktur dentoalveolar regio gigi 21-22, 31-42 disertai avulsi gigi $21,22,31,41,42$ dan vulnus laseratum regio labii superior et inferior et regio palatum et regio gingiva gigi 21-22 dan 31-42.

Sebelum dilakukan tindakan sesuai prosedur tetap dilakukan penjelasan pada pasien dan keluarga tentang tahap-tahap perawatan dan keluarga pasien menandatangani surat persetujuan tindakan medis. Untuk publikasi ilmiah pasien telah menandatangani surat persetujuan saat pasien dilakukan tindakan definitif Open Reduction Internal Fixation. Tindakan emergensi yang dilakukan dari bagian Bedah Saraf adalah observasi kesadaran pasien dengan penilaian GCS, dan tanda vital, posisi kepala pasien 30 derajat, oksigenasi dengan nasal kanul 2-4 liter per menit, pemasangan infus $\mathrm{NaCl}$ 0,9\% 1500 cc per hari, dan dilakukan perawatan konservatif non operatif. Sedangkan tindakan emergensi dari bagian Bedah Mulut dan Maksilofasial adalah penyuntikan obat anti tetanus serum (ATS) dan tetanus toxoid (TT), antibiotik Ceftriaxone $1 \mathrm{gram}$, analgetik Ketorolac 30 miligram dan $\mathrm{H} 2$ blocker berupa Ranitidine 50 miligram sebelum tindakan dilakukan.

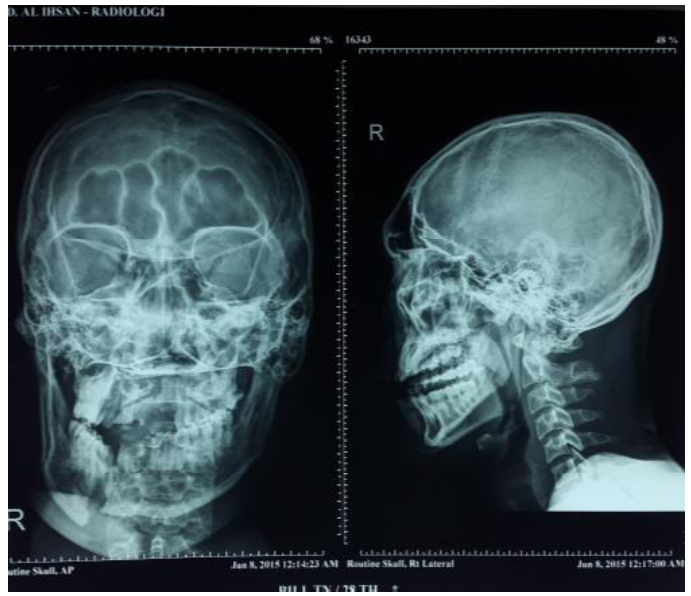

(A)

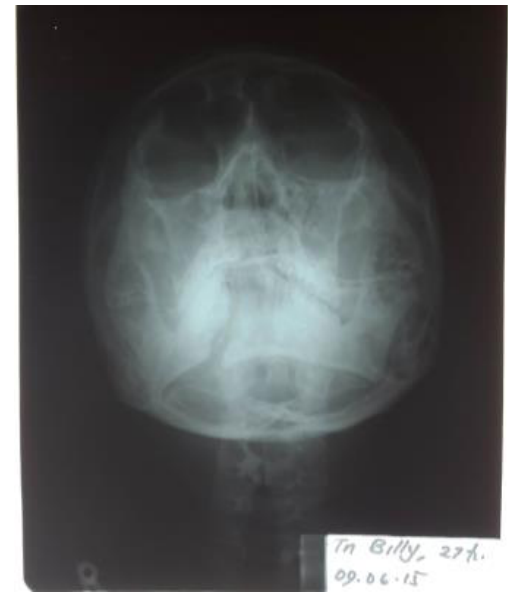

(B)

Gambar 4. (A) Foto polos kepala AP-lateral, (B) Foto Water's, kesan fraktur Le fort II, fraktur palatum, fraktur parasimfisis mandibula dextra, fraktur dentoalveolar rahang atas dan rahang bawah. 


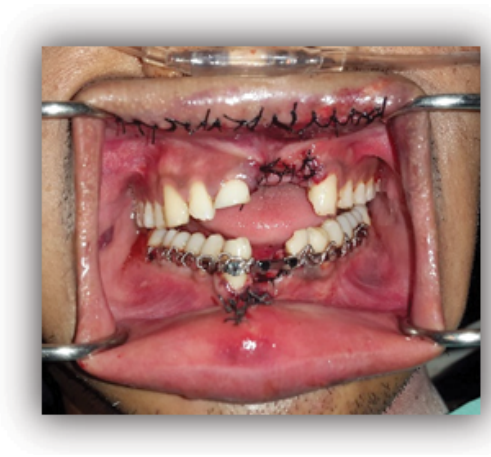

(A)

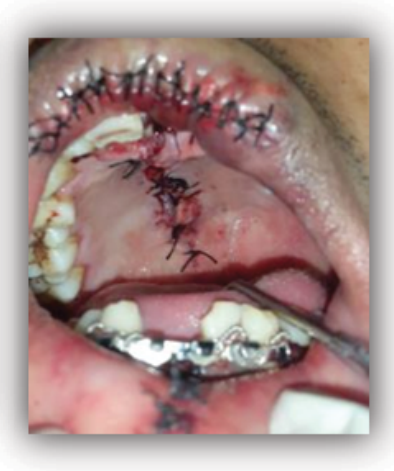

(B)

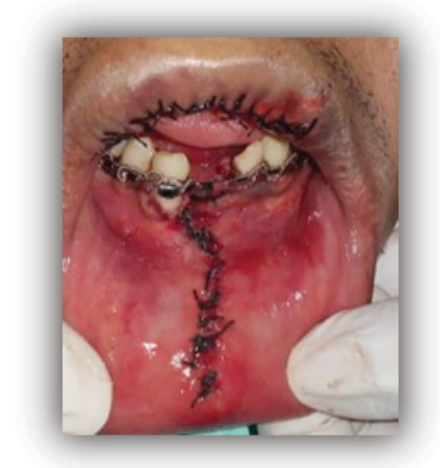

(C)

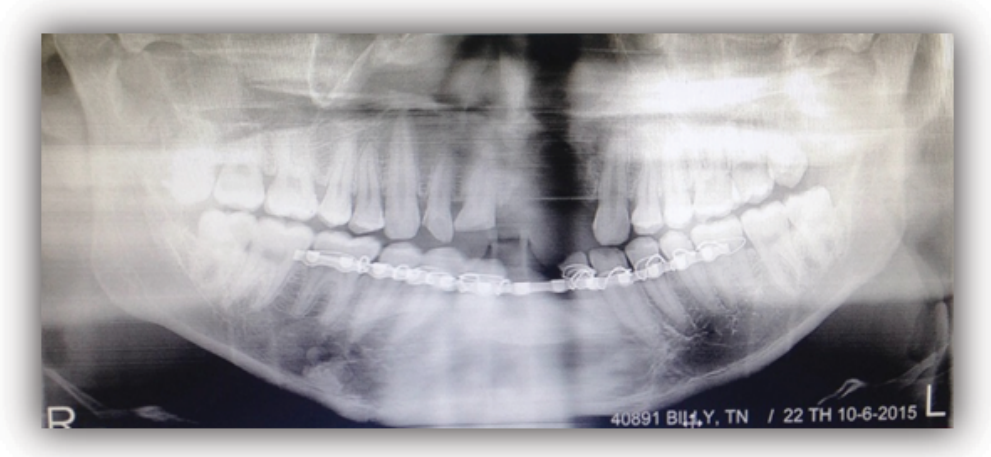

(D)

Gambar 5. Gambaran Intra oral paska tindakan Bedah Mulut dan Maksilofasial: (A). Posisi oklusi paska pemasangan IDW Erich Bar pada rahang bawah. (B) dan (C) Post penjahitan laserasi intraoral. (D). Foto panoramik setelah pasien masuk ruang rawat inap.

Pembersihan luka dilakukan dengan menggunakan $\mathrm{NaCl}$ 0,9\% yang dicampur dengan Gentamicin, dengan perbandingan $500 \mathrm{cc} \mathrm{NaCl}$ $0,9 \%$ dicampur Gentamicin $2 \mathrm{cc} \quad(10 \mathrm{mg} / \mathrm{cc})$. Alveolectomy pada regio gigi 21-22 dan 31-42, luka laserasi intraoral dijahit menggunakan silk 4.0 dan pada luka laserasi ekstraoral dijahit menggunakan nilon 6.0 dengan menggunakan anestesi lokal. Fiksasi sementara dilakukan menggunakan Inter Dental Wiring (IDW) Erich Bar pada rahang bawah dari gigi 36-46 dan direncanakan akan dilakukan Open Reduction Internal Fixation (ORIF) secara elektif setelah 14 hari paska kecelakaan lalu lintas. Setelah tindakan tersebut kemudian pasien dipindahkan ke ruang rawat inap dan dirawat bersama antara bagian Bedah Saraf dan Bedah Mulut dan Maksilofasial dimana bagian Bedah Saraf sebagai dokter penanggung jawab klinik.

\section{PEMBAHASAN}

Penatalaksanaan emergensi pada pasien trauma oromaksilofasial yang disertai fraktur basis kranii anterior harus mendapat perhatian segera pada saluran pernapasan, adekuasi dari ventilasi, kontrol perdarahan internal dan eksternal serta observasi kebocoran cairan serebro spinal. ${ }^{12,13}$ Penilaian awal (primary survey) pada kasus pasien trauma ini bedasarkan Advance Trauma Life Support (ATLS), dari American College of Surgeons (ACS). Primary survey berupa penilaian Airway clear with C-Spine control, Breathing-ventilation-oxygenation, Circulation, Disability-neurologic status, dan Exposure-environment, body temperature (ABCDE). Penilaaan $A B C D E$ merupakan prioritas pemeriksaan berdasarkan jenis luka, tanda vital dan mekanisme cedera, sehingga keadaan yang mengancam nyawa dengan cepat dikenali dan resusitasi segera dilakukan.

Pemeriksaan jalan nafas pada pasien ini didapati Airway clear with C-Spine control, perdarahan intra oral, dan tidak menggangu jalan nafas, serta tidak terdapat obstruksi. Usaha untuk membebaskan jalan nafas dilakukan dengan menjaga jalan nafas dari perdarahan intra oral 
dengan tindakan suctioning dan melindungi vertebra servikal serta dengan pemasangan airway definitif jika diperlukan. ${ }^{12,13,14}$

Breathing, ventilation, oxygenation diberikan dengan nasal kanul 2-4 liter per menit, dan evaluasi ventilasi secara cepat meliputi fungsi paru, dinding dada dan diafragma. Circulation dengan pemasangan infus $\mathrm{NaCl} 0,9 \% 20$ tetes per menit, untuk menjaga keadaan hemodinamik pasien tetap stabil dan secara simultan dilakukan pemeriksaan darah lengkap serta faktor pembekuan darah. Sumber perdarahan eksternal pada pasien ini tidak ditemukan. ${ }^{12,13,14}$ Disability, neurologic status pada pasien ini dievaluasi menggunakan GCS, pasien mampu membuka mata spontan ukuran dan reaksi pupil tidak terdapat tanda-tanda lateralisasi, motorik mampu mengikuti perintah, dan komunikasi verbal baik. ${ }^{12,13,14}$

Exposure, environment, body temperature, pakaian pasien dibuka untuk melakukan pemeriksaan secara menyeluruh, kelainan-kelainan yang mungkin terlewat pada pemeriksaan sebelumnya, seperti adanya darah yang keluar dari anus atau luka pada tubuh yang tertutup pakaian, setelah pakaian dilepas pasien segera diselimuti untuk mencegah hipotermi. Pemeriksaan pada pasien ini ditemukan jejas luka abrasi pada regio leher dan dada kemudian dilakukan pemeriksaan foto rontgen thoraks Antero Posterior (AP) dan foto servical, dengan hasil dalam batas normal. 12,13,14 $^{2}$

Pemeriksaan secondary survey pada pasien ini dilakukan dengan prinsip head to toe examination berupa prosedur penunjang seperti anamnesis, pemeriksaan fisik ekstra oral, kepala dan oromaksilofasial, pemeriksaan intra oral yang meliputi status lokalis gigi dan jaringan pendukung sekitarnya, pemeriksaan radiologis dan laboratorium dapat dikerjakan pada kesempatan ini. ${ }^{12,13,14}$

Adanya kebocoran cairan serebro spinal pada pasien ini ditemukan berdasarkan ditemukannya rhinorrhea dan 'halo sign' yang diidentifikasi berdasarkan ditemukan cairan serebro spinal berada di luar pada linen dan membentuk cincin dari darah atau mukus berada ditengahnya. ${ }^{8,9,10}$ Penatalaksanaan pada pasien fraktur basis kranii dapat dilakukan secara non operatif atau operatif, pada pasien ini dilakukan tindakan non operatif dimana indikasinya pada trauma akut, dilakukan observasi terlebih dahulu, dan pada kebanyakan kasus sembuh secara spontan. Pemberian antibiotik profilaksis, bed rest dengan elevasi kepala 30 derajat, dan pemberian asetazolamid dengan dosis $250 \mathrm{mg} / 6$ jam untuk menekan produksi cairan serebro spinal. $8,9,10,11$

Indikasi untuk tindakan operatif dilakukan oleh bagian Bedah Saraf jika penanganan konservatif gagal oleh karena kebocoran cairan serebro spinal persisten kurang dari dua minggu, rekuren atau delayed onset kebocoran cairan serebro spinal setelah 10 hari. Pneumocephalus dengan volume besar, rekuren pneumocephalus setelah 10 hari, meningitis, trauma penetrans, dan adanya perdarahan intrakranial merupakan indikasi dilakukan tindakan operatif. $8,9,10,11$

Penatalaksanaan emergensi Bedah Mulut dan Maksilofasial pada pasien ini meliputi perawatan umum terhadap komplikasi yang menyertai, pemeriksaan klinis yang teliti, interpretasi foto rontgen yang tepat, menentukan tipe dan macam fraktur. Tindakan dilakukan segera dan cepat dengan minimal intervensi pada rahang atas bertujuan untuk mencegah kebocoran cairan serebro spinal persisten, dan mencegah terjadinya infeksi meningitis. Manajemen luka jaringan lunak dan jaringan keras, melakukan reduksi, fiksasi dan imobilisasi fraktur dengan menggunakan Inter Dental Wiring (IDW) Erich Bar, manajemen nyeri serta pemberian antibiotik dilakukan secara simultan. ${ }^{1,2,3,9,10,11}$

\section{KESIMPULAN}

Penatalaksanaan emergensi trauma oromaksilofasial disertai fraktur basis kranii anterior dilakukan segera dan cepat dengan minimal intervensi untuk mencegah kebocoran cairan serebro spinal persisten, dan terjadinya infeksi meningitis. Manajemen luka jaringan lunak dan jaringan keras, melakukan reduksi, fiksasi dan imobilisasi fraktur, manajemen nyeri serta pemberian antibiotik. Seorang ahli Spesialis Bedah Mulut dan Maksilofasial dalam melakukan tindakan emergensi harus mengetahui dan menguasai penilaian awal 
pada pasien trauma berdasarkan prinsip-prinsip Advance Trauma Life Support (ATLS).

\section{DAFTAR PUSTAKA}

1. Pedersen GW. Buku ajar praktis bedah mulut. Penerjemah: Purwanto dan Basoeseno. Jakarta: EGC; 1996. 221-263.

2. Raymond J. Fonseca. Oral and maxillofacial trauma. $4^{\text {th }}$ edition. St. Louis, Missouri. Saunders. 2013. part II. chap 4.

3. Engin DA, Alper GS, Erdal K, Cemil K, Fevzi $\mathrm{Y}$, Evvah K, Tamer D, Muge S. Assessment of maxillofacial trauma in emergency department. WJES. Turkey. 2014; 9: 13.

4. Zollman FS. Manual of traumatic brain injury management. New York: Demos Medical; 2011. 25-31.

5. Corrigan J, Selassie A, Orman J. The epidemiology of traumatic brain injury. $\mathrm{J}$ Head Trauma Rehabil. 2010; 25: 72-80.

6. Satyanegara. IImu bedah saraf. Edisi V. Jakarta: Gramedia Pustaka Utama; 2014. 322.

7. Greenberg MS. Handbook of neurosurgery $7^{\text {th }}$ edition. Canada: Thieme; 2010. 297-306.

8. Francis B. Quinn. Melinda Stoner Quinn. Basilar Skull Fractures [Internet]. Grand Rounds Presentation. The University of Texas Medical Branch in Galveston. Journal of Otolaryngology; 2013 [cited 2015 July 13].
Available from Netlibrary: https://www.utmb. edu/otoref/Grnds/basilar-skull-fx-2013-12/ basilar-skull-fx-2013-12.pdf.

9. Tseng WC, Shih HM, Su YC, Chen HW, Hsiao KY, Chen IC. The association between skull bone fractures and outcomes in patients with severe traumatic brain injury. The Journal of Trauma. 2011; 71: 1611-1614.

10. Katzen JT, Jarrahy R, Eby JB, Mathiasen RA, Margulies DR, Shahinian HK. Craniofacial and skull base trauma. The Journal of Trauma Injury, Infection, and Critical Care. 2003; 54: 1026-1034.

11. Eftekhar B, Ghodsi M, Nejat F, Ketabchi E, Esmaeeli B. Prophylactic administration of ceftriaxone for the prevention of meningitis after traumatic penumocephalus: results of a clinical trial. J Neurosurg. 2004; 101: 757-761.

12. Peter WB, Barry E, Rainer S. Maxillofacial trauma and esthetic facial reconstruction. $2^{\text {nd }}$ edition.St. Louis, Missouri.Saunders; 2013. 28-58.

13. Bell RB, Dierks EJ, Homer L, Potter BE. Management of cerebrospinal fluid leak associated with craniomaxillofacial trauma. $\mathrm{J}$ Oral Maxillofacial Surgery. 2004; 62(6): 67684.

14. Nancy P. American college of surgeon. Head injury. Advance Trauma Life Support. $9^{\text {th }}$ edition. Chicago. 633 N. Saint Clair Street; 2012. 176-235. 